Article

\title{
Effects of Canola Oil Biodiesel Fuel Blends on Combustion, Performance, and Emissions Reduction in a Common Rail Diesel Engine
}

\author{
Sam Ki Yoon ${ }^{1}$, Min Soo Kim ${ }^{2}$, Han Joo Kim ${ }^{2, *}$ and Nag Jung Choi ${ }^{2, *}$ \\ 1 Technical Education Center, GM Korea Company, 72 Saengmuol-ro, Gunsansi, \\ Jeollabuk-do 573-882, Korea; E-Mail: sky596072@hanmail.net \\ 2 Division of Mechanical Design Engineering, Chonbuk National University, 567 Baekje-daero, \\ Jeonjusi, Jeollabuk-do 561-756, Korea; E-Mail: kimms@jbnu.ac.kr \\ * Authors to whom correspondence should be addressed; \\ E-Mails: khanjoo@jbnu.ac.kr (H.J.K.); njchoi@jbnu.ac.kr (N.J.C.); \\ Tel.: +82-63-270-4765 (N.J.C.); Fax: +82-63-270-2460 (N.J.C.).
}

External Editor: Joshua Swithenbank

Received: 29 September 2014; in revised form: 19 November 2014 / Accepted: 1 December 2014 / Published: 5 December 2014

\begin{abstract}
In this study, we investigated the effects of canola oil biodiesel (BD) to improve combustion and exhaust emissions in a common rail direct injection (DI) diesel engine using BD fuel blended with diesel. Experiments were conducted with BD blend amounts of $10 \%$, $20 \%$, and $30 \%$ on a volume basis under various engine speeds. As the BD blend ratio increased, the combustion pressure and indicated mean effective pressure (IMEP) decreased slightly at the low engine speed of $1500 \mathrm{rpm}$, while they increased at the middle engine speed of $2500 \mathrm{rpm}$. The brake specific fuel consumption (BSFC) increased at all engine speeds while the carbon monoxide (CO) and particulate matter (PM) emissions were considerably reduced. On the other hand, the nitrogen oxide $\left(\mathrm{NO}_{x}\right)$ emissions only increased slightly. When increasing the BD blend ratio at an engine speed of $2000 \mathrm{rpm}$ with exhaust gas recirculation (EGR) rates of $0 \%, 10 \%, 20 \%$, and $30 \%$, the combustion pressure and IMEP tended to decrease. The $\mathrm{CO}$ and $\mathrm{PM}$ emissions decreased in proportion to the $\mathrm{BD}$ blend ratio. Also, the $\mathrm{NO}_{x}$ emissions decreased considerably as the EGR rate increased whereas the BD blend ratio only slightly influenced the $\mathrm{NO}_{x}$ emissions.
\end{abstract}


Keywords: canola oil biodiesel blends; exhaust gas recirculation; combustion characteristics; exhaust emissions; diesel engine

\section{Introduction}

Over the past few decades, global warming has intensified due to the drastic increase in greenhouse gases (GHG) produced by fossil fuels. Abnormal climate change resulting from global warming has caused phenomena such as floods, sudden rainstorms, intense heat, and typhoons. Climate change and the mitigation of GHG emissions has become a primary motivation for biofuels research. Furthermore, growing concerns of environmental pollution caused by the extensive use of conventional fossil fuels has led to the search for more environmentally friendly and renewable fuels. Therefore, biofuels such as alcohols and biodiesel have been proposed as alternatives for internal combustion engines [1,2]. In particular, biodiesels derived from vegetable oils have received wide attention as a replacement for diesel fuel because they emit less GHG and other pollutant emissions. Diesel engines are mostly used in industrial transportation, passenger car, and agricultural applications. Despite their disadvantages including noise and vibration, they have a high thermal efficiency, large power output, and are highly reliable. However, a diesel engine emits relatively more particulate matter (PM) and nitrogen oxide $\left(\mathrm{NO}_{x}\right)$ than a gasoline engine [3-5]. Furthermore, the regulations for $\mathrm{PM}$ and $\mathrm{NO}_{x}$ emissions from diesel have strengthened and their emissions are an important environmental issue [6]. Therefore, many researchers have studied ways to reduce exhaust emissions such as $\mathrm{PM}$ and $\mathrm{NO}_{x}$ by the use of diesel particulate filters (DPF), selective catalytic reduction (SCR) [7,8], and alternative fuels which can be used without requiring modification of the diesel engine [9-12]. Biodiesel fuels can be produced from various vegetable oils, waste cooking oils, and animal fats. The fuel properties of biodiesel may change when different feed stocks are used [13-15]. In general, if the fuel properties of biodiesel are compared to petroleum diesel fuel, biodiesel has a higher viscosity, density, and cetane number. Moreover, it has been reported that biodiesel can reduce tailpipe emissions because it has a sufficient amount of oxygen in its molecular structure [16-19]. However, biodiesel must be blended with pure diesel because the net calorific value of biodiesel is less than that of conventional diesel fuel. Ileri et al. [20] experimentally analyzed the effect of antioxidants on the engine performance and exhaust emissions of a diesel engine fueled with a canola oil methyl ester (COME) and diesel blend. They reported that the addition of antioxidants did not cause any negative effect on the basic fuel properties of COME blended with diesel. Ozsezen et al. [15] investigated the performance and combustion characteristics of a direct injection diesel engine with neat biodiesel such as palm oil and canola oil where they demonstrated that the engine performance was slightly weakened and the combustion characteristics such as carbon monoxide (CO), unburned hydrocarbon (HC), and smoke capacity changed slightly compared to pure diesel fuel.

The high oxygen content in biodiesel results in improvement of its combustion efficiency as well as reductions of $\mathrm{PM}, \mathrm{CO}$, and $\mathrm{HC}$ emissions but at the same time, produces higher $\mathrm{NO}_{x}$ emissions [21-25]. There are various problems associated with vegetable oils being used as fuel in diesel engines due to the high viscosity, density, iodine value, and poor volatility of the vegetable oil. Researchers have clearly proven that trans-esterification is the best way to use vegetable oil as a fuel in existing diesel 
engines [26,27]. The high viscosity and surface tension of biodiesel affect atomization by increasing the mean droplet size which, in turn, increases the spray tip penetration. The higher mean droplet size of biodiesel is due to the lower Weber number, which is due to the high surface tension [28]. Jindal et al. [29] researched the effects of the injection pressure on engine performance with regard to the brake specific fuel consumption (BSFC) and break thermal efficiency (BTE) when Jatropha methyl ester was used as a fuel. It was found that increasing the injection pressure increases the BTE and reduces the BSFC. Canola is a popular biodiesel feedstock because it produces more oil per unit of land area compared to other oil sources. Therefore, many studies have investigated the trans-esterification reaction of canola oil for biodiesel production and evaluated its ester in diesel engines with regard to engine performance and combustion characteristics [5,20,30]. Roy et al. [31] tested canola oil biodiesel (BD)-diesel blends at high idling operations. The results showed that the $\mathrm{CO}$ and $\mathrm{HC}$ emissions were significantly reduced compared to pure diesel fuel. In addition, with up to 5\% BD blends, the $\mathrm{NO}_{x}$ emissions did not increase whereas $\mathrm{NO}_{2}$ production at high idling was more than $50 \%$ of the total $\mathrm{NO}_{x}$ emissions. Lee et al. [28] reported a method of injection when using ultralow sulfur diesel (ULSD) and biodiesel on a common rail diesel engine. They showed that with a higher biodiesel blend ratio, a higher injection pressure is required due to the larger surface tension of biodiesel. Al-Dawody et al. [32] suggested various strategies such as cooling the air temperature, retarding the injection timing, optimizing the piston bowl design, exhaust gas recirculation (EGR), and increasing the nozzle diameter as methods to reduce the soybean biodiesel $\mathrm{NO}_{x}$ effect in a diesel engine. Among the various strategies, they found that the most significant reduction of $\mathrm{NO}_{x}$ emissions resulted from retarding the injection timing and increasing the nozzle diameter. On the other hand, the decreasing level of $\mathrm{NO}_{x}$ was accompanied by considerable increases of the smoke emissions and fuel consumption. From the literature review, the effects of canola oil biodiesel fuel blends on the combustion characteristics and exhaust emissions reduction in a direct injection (DI) diesel engine injected under a high pressure has not been clearly studied when using canola oil fuels blended with diesel. Therefore, these topics need to be investigated to address this deficiency in the literature. For this reason, in present study, the effects of BD fuel blends and the EGR rate on the combustion and exhaust emissions characteristics in a common rail diesel engine were experimentally investigated.

\section{Experimental Materials and Methods}

\subsection{Test Fuels and Operating Conditions}

BD was blended with pure diesel at $10 \%, 20 \%$, and $30 \%$ on a volume basis. The fuels were characterized by determining their viscosity, density, pour point, distillation temperature, flash point, acid number, ester content, total free glycerin, and calculated index. In order to measure the fuel properties of pure diesel, neat BD, and the BD blends, the ASTM-D6751 and EN-14214 standard test methods were used. The fuel properties of the pure diesel, neat BD, and BD blended fuels are presented in Table 1. 
Table 1. Properties of pure diesel, neat biodiesel and biodiesel (BD) blends.

\begin{tabular}{ccccccc}
\hline Properties (units) & Pure diesel & Neat BD & BD 10 & BD 20 & BD 30 & Test method \\
\hline Density $\left(\mathrm{kg} / \mathrm{mm}^{3}\right.$ at $\left.15^{\circ} \mathrm{C}\right)$ & 836.8 & 880 & 842 & 846 & 850 & ASTM D941 \\
Viscosity $\left(\mathrm{mm}^{2} / \mathrm{s}\right.$ at $\left.40{ }^{\circ} \mathrm{C}\right)$ & 2.719 & 4.290 & 2.818 & 2.991 & 3.172 & ASTM D445 \\
Calorific value $(\mathrm{MJ} / \mathrm{kg})$ & 43.96 & 39.49 & 43.29 & 42.71 & 42.12 & ASTM D4809 \\
Cetane index & 55.8 & 61.5 & - & - & - & ASTM D4737 \\
Flash point $\left({ }^{\circ} \mathrm{C}\right)$ & 55 & 182 & - & - & - & ASTM D93 \\
Pour point $\left({ }^{\circ} \mathrm{C}\right)$ & -21 & -8 & - & - & - & ASTM D97 \\
Oxidation stability $\left(\mathrm{h} / 110^{\circ} \mathrm{C}\right)$ & 25 & 15 & - & - & - & EN 14112 \\
Ester content $(\%)$ & - & 98.9 & - & - & - & EN 14103 \\
Oxygen $(\%)$ & 0 & 10.8 & - & - & - & - \\
\hline
\end{tabular}

In this study, BD was used along with BD blends and ULSD, which had a sulfur content of $0.005 \%$, for comparison. In order to investigate the characteristics of combustion and exhaust emissions depending on the BD blend ratio, tests were carried out at the warmed up condition of the engine under four different engine speeds: 1000, 1500, 2000, and $2500 \mathrm{rpm}$. In addition, the coolant temperature was held constant at $70 \pm 3{ }^{\circ} \mathrm{C}$, the intake air temperature was $20 \pm 3{ }^{\circ} \mathrm{C}$, and a constant load of $30-\mathrm{N} \cdot \mathrm{m}$ torque from the engine dynamometer was applied to the test engine at each speed in order to ensure consistent test conditions. The experimental and operating conditions are summarized in Table 2.

Table 2. Experiment and operating conditions.

\begin{tabular}{ccc}
\hline Test parameters & Unit & Operating condition \\
\hline Engine speed & rpm & $1000,1500,2000,2500$ \\
Torque & N.m & 30 \\
\hline Test fuels & - & BD blended rate with diesel (vol. \%) \\
0 & - & Diesel $100 \%+$ BD $0 \%$ \\
BD 10 & - & Diesel $90 \%+$ BD $10 \%$ \\
BD 20 & - & Diesel $80 \%+$ BD $20 \%$ \\
BD 30 & - & Diesel $70 \%+$ BD $30 \%$ \\
\hline Cooling water temp. & ${ }^{\circ} \mathrm{C}$ & $70 \pm 3$ \\
Intake air temp. & ${ }^{\circ} \mathrm{C}$ & $20 \pm 3$ \\
Gas recirculation (EGR) rate & ${ }^{\%}$ & $0,10,20,30$ \\
Injection pressure & $\mathrm{MPa} / \mathrm{rpm}$ & $30 / 1000,37 / 1500,45 / 2000,60 / 2500$ \\
\hline
\end{tabular}

\subsection{Test Engine and Experimental Procedure}

In this study, the experimental apparatus consisted of the components shown in Figure 1. This apparatus was used to investigate the combustion and exhaust emission characteristics as functions of the $\mathrm{BD}$ blend ratio and EGR rate in a 4-cylinder common rail diesel engine. The experimental equipment consisted of a 4-cylinder electronic common rail diesel engine equipped with a turbocharger, a fuel consumption rate tester with a fuel pump driven by an electrical voltage of $220 \mathrm{~V}$, a control unit connected to an electronic control unit (ECU) to control the injection timing, and an eddy current type EC dynamometer (DY-230kW, Hwanwoong, Korea) to control the engine speed. A piezoelectric pressure sensor (6056a, Kistler, Swiss) was mounted onto the position of the glow plug to measure the 
combustion pressure. Data was then acquired using a data acquisition board (PCI6040E, National Instrument, Austin, TX, USA). The combustion pressure in the cylinder was analyzed using a combustion analyzer. The main specifications of the 4-cylinder common rail diesel engine used in this study are summarized in Table 3. The EGR rate (\%) is defined as the difference between the quantity of fresh air induced without EGR $\left(Q_{0}\right)$ and that of air with EGR $\left(Q_{\mathrm{EGR}}\right)$ divided by the quantity of fresh air induced without EGR $\left(Q_{0}\right)$, as shown below:

$$
\operatorname{EGR}(\%)=\frac{Q_{0}-Q_{\mathrm{EGR}}}{Q_{0}} \times 100
$$

Figure 1. Schematic diagram of the experimental apparatus. HC: hydrocarbon; ECU: electronic control unit; ESR: gas recirculation; CO: carbon monoxide.

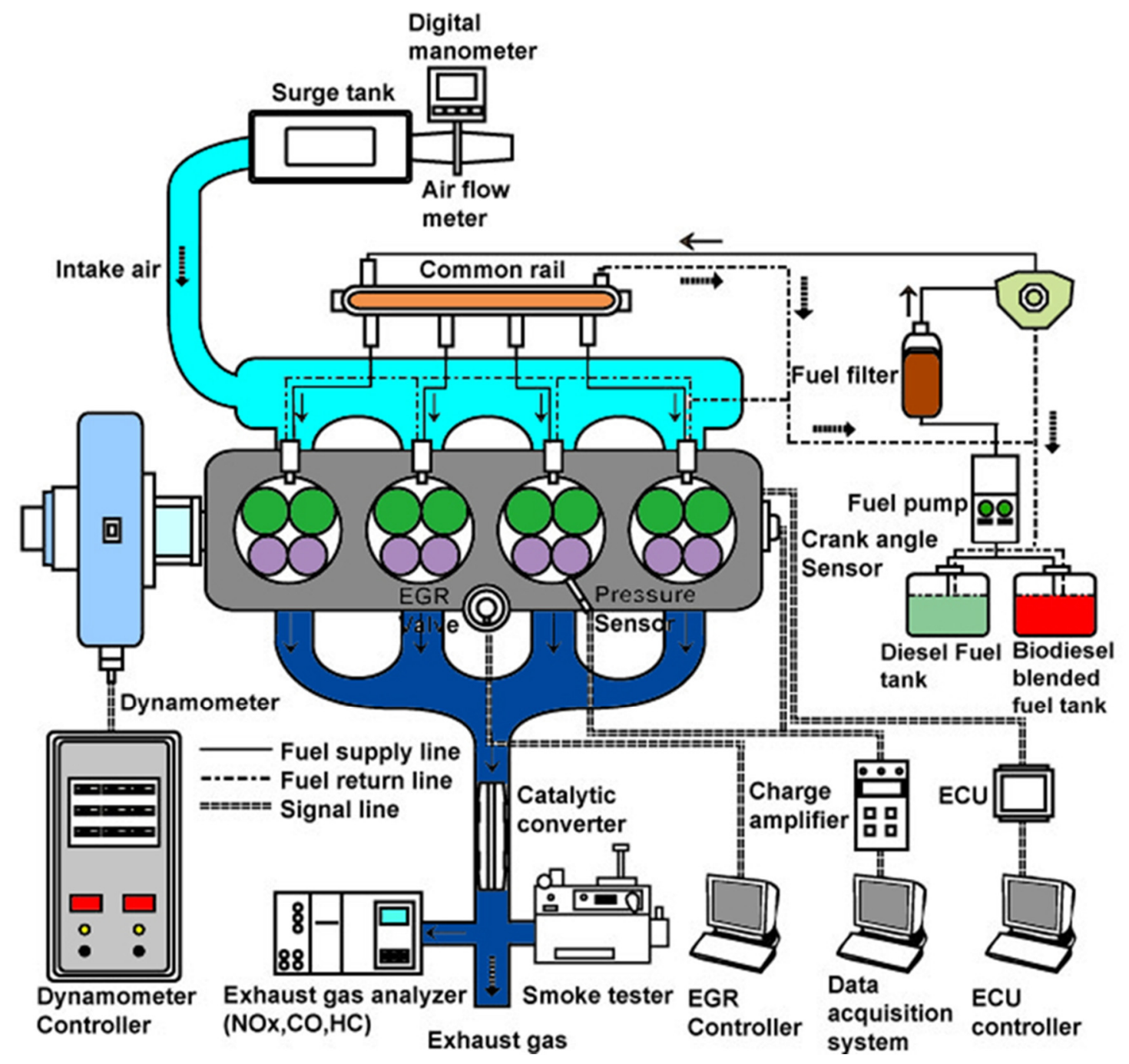


Table 3. Specifications of the test engine.

\begin{tabular}{ccc}
\hline Test model & Parameter (units) & Specification \\
\hline & Engine type & 4 -cylinder \\
& Bore $(\mathrm{mm})$ & 81 \\
Stroke $(\mathrm{mm})$ & 96 \\
Engine type & Displacement $\left(\mathrm{cm}^{3}\right)$ & 1979 \\
& Combustion type & Direct injection \\
& Injection procedure & $1-3-4-2$ \\
Compression ratio & $17.7: 1$ \\
& Maximum power $(\mathrm{kW} / \mathrm{rpm})$ & $82 / \mathrm{at} 4000$ \\
& Maximum torque $(\mathrm{N} \cdot \mathrm{m} / \mathrm{rpm})$ & $260 /$ at 2000 \\
& Maximum engine speed $(\mathrm{rpm})$ & 4500 \\
\hline \multirow{2}{*}{ Fuel injection system } & Fuel control & ECU control \\
& Maximum fuel pressure $(\mathrm{MPa})$ & 145 \\
& Number of injector nozzle holes & 5 \\
& Injector spray angle $($ degree $)$ & 150 \\
& Injector hole diameter $(\mathrm{mm})$ & 0.17 \\
\hline
\end{tabular}

The exhaust gas was delivered to the intake manifold through a water-cooled unit by an EGR valve and the gas flow rate was regulated by controlling the EGR duty ratio using a computer. The $\mathrm{NO}_{x}$ emissions were monitored in real time using an exhaust analyzer. Exhaust measuring equipment was used for the exhaust component analysis. A multi-gas analyzer (MK2, Eurotron, Italy) was used to measure the $\mathrm{O}_{2}, \mathrm{CO}, \mathrm{NO}, \mathrm{NO}_{2}$, and $\mathrm{HC}$ contents of the exhaust gases. In order to detect $\mathrm{PM}$, an opacity smoke meter (OPA-102, Qurotech, Korea) was also utilized using the partial flow sampling method. The gas analyzer specifications along with the resolution, range, and accuracy are summarized in Table 4. In this work, the heat release rate (HRR) of $\mathrm{BD}$ combustion in the engine was calculated using the following formula [33]:

$$
\frac{\mathrm{d} Q}{\mathrm{~d} \theta}=\frac{k}{k-1} P \frac{\mathrm{d} V}{\mathrm{~d} \theta}+\frac{1}{k-1} V \frac{\mathrm{d} P}{\mathrm{~d} \theta}
$$

Here, $\mathrm{d} Q / \mathrm{d} \theta$ is the HRR, $k$ is the specific heat ratio which was assumed to be $1.35, \mathrm{~d} P / \mathrm{d} \theta$ is the rate of change of the pressure, and $\mathrm{d} V / \mathrm{d} \theta$ is the rate of change of the cylinder volume. BSFC is defined as the ratio of fuel consumption rate to the brake power of the engine. The value was calculated based on the fuel consumption, engine torque, and speed data using the following formula:

$$
b_{\mathrm{f}}=\frac{\dot{m}_{\mathrm{f}}}{2 \pi N T_{\mathrm{e}}}
$$

Here, $b_{\mathrm{f}}$ is the brake specific fuel consumption rate, $\dot{m}_{\mathrm{f}}$ is the fuel consumption flow rate into the cylinder, $N$ is the engine speed, and $T_{\mathrm{e}}$ is the brake torque, which was directly measured using an engine dynamometer. The brake specific energy consumption (BSEC) is also known as the ratio of the energy consumption rate to the brake power of the engine, which is calculated from the fuel consumption and low heating calorific value using the following formula:

$$
b_{\mathrm{e}}=\frac{Q_{\mathrm{LHV}} B_{\mathrm{f}}}{2 \pi N T_{\mathrm{e}}}
$$


Here, $b_{\mathrm{e}}$ is the brake specific energy consumption rate, $B_{\mathrm{f}}$ is the fuel consumption mass per hour, and $Q_{\mathrm{LHV}}$ is the low heating calorific value, which is directly measured by the engine dynamometer.

Table 4. Specifications of the exhaust gas analyzer. PM: particulate matter.

\begin{tabular}{cccccc}
\hline Method of detection & Species & Unit & Range & Resolution & Accuracy \\
\hline Electrochemical & $\mathrm{O}_{2}$ & $\%$ & $0 \%-30 \%$ & $0.1 \%$ & $\pm 0.57 \%$ \\
Electrochemical & $\mathrm{CO}$ & $\mathrm{ppm}$ & $0-4000 \mathrm{ppm}$ & $1 \mathrm{ppm}$ & $\pm 0.62 \%$ \\
Pellistor & $\mathrm{HC}$ & $\%$ & $0 \%-5 \%$ & $0.01 \%$ & $\pm 0.8 \%$ \\
Electrochemical & $\mathrm{NO}$ & $\mathrm{ppm}$ & $0-5000 \mathrm{ppm}$ & $1 \mathrm{ppm}$ & $\pm 0.25 \%$ \\
Electrochemical & $\mathrm{NO}_{2}$ & $\mathrm{ppm}$ & $0-1000 \mathrm{ppm}$ & $1 \mathrm{ppm}$ & $\pm 0.25 \%$ \\
Smoke opacity & $\mathrm{PM}$ & $\%$ & $0 \%-100 \%$ & $0.1 \%$ & $\pm 1 \%$ \\
\hline
\end{tabular}

\section{Results and Discussion}

\subsection{Effects of Biodiesel on Combustion and Emissions}

\subsubsection{Combustion and Engine Performance}

Figure 2 shows the combustion pressure and HRR as functions of the engine speed at the various BD blend ratios in the diesel engine without EGR. As shown in Figure 2a, at the low engine speed of $1500 \mathrm{rpm}$, the combustion pressure decreased slightly by $5.9 \%$ with BD $10,4.6 \%$ with BD 20 , and $6.9 \%$ with BD 30 compared to that of BD 0. On the other hand, at the middle engine speed of $2500 \mathrm{rpm}$, the combustion pressure increased to $3.3 \%$ with $\mathrm{BD} 10,2.8 \%$ with $\mathrm{BD} 20$, and $6.6 \%$ with $\mathrm{BD} 30$. These results demonstrate that the combustion pressure with $\mathrm{BD} 0$ is slightly higher at the low engine speed of $1500 \mathrm{rpm}$. As Table 1 shows, the kinetic viscosity of BD is $50.4 \%$ higher than that of ULSD. For these reasons, in the case of BD 0, it is estimated that at low engine speeds in the range of $1500 \mathrm{rpm}$, this higher viscosity disturbs the atomization of fuel during injection. As shown in Figure $2 b$, at the middle engine speed range, as the BD blend ratio increases, the combustion pressure increases. This is due to the improvement of conditions caused by the higher fuel injection pressure at $2500 \mathrm{rpm}$ including the spray droplet size, fuel injection speed, and catalyzed combustion activation. In addition, Figure 2 shows that the HRR is greater than that of ULSD. At an engine speed of $1500 \mathrm{rpm}$, as the BD blend ratio increases, the HRR increases by $9.5 \%$ with BD 10, $11.4 \%$ with BD 20, and 10.8\% with BD 30 compared to the value obtained with BD 0 . At an engine speed of $2500 \mathrm{rpm}$, the HRR increased considerably up to $22.5 \%$ with BD $10,21.5 \%$ with BD 20 , and $24.8 \%$ with BD 30 compared to the value obtained for BD 0. For this reason, it is seen that the HRR of BD is higher than that of ULSD because BD holds sufficient oxygen which catalyzes combustion activation.

Figure 3 shows the peak combustion pressure and indicated mean effective pressure (IMEP) as functions of the engine speed without EGR when increasing the BD blend ratio. As shown in Figure 3, the peak combustion pressure shows slight tendencies to decrease until the engine speed reached 2000 rpm with increasing BD blend ratio, however, IMEP presents an increasing trend as biodiesel percentage in the blend is increased under all different engine speed values. On the other hand, at $2500 \mathrm{rpm}$, the peak combustion pressure increased by $3.3 \%$ with $\mathrm{BD} 10,2.8 \%$ with $\mathrm{BD} 20$, and $6.6 \%$ with $\mathrm{BD} 30$, compared to BD 0. For this reason, the combustion pressure increased at $2500 \mathrm{rpm}$ with increasing BD 
blend ratio, which is caused by the accelerated combustion of fuel which is atomized by a high injection pressure and the oxygen contained in the BD.

Figure 2. Effects of the biodiesel blend ratio on the combustion characteristics at (a) 1500 and (b) $2500 \mathrm{rpm}$.

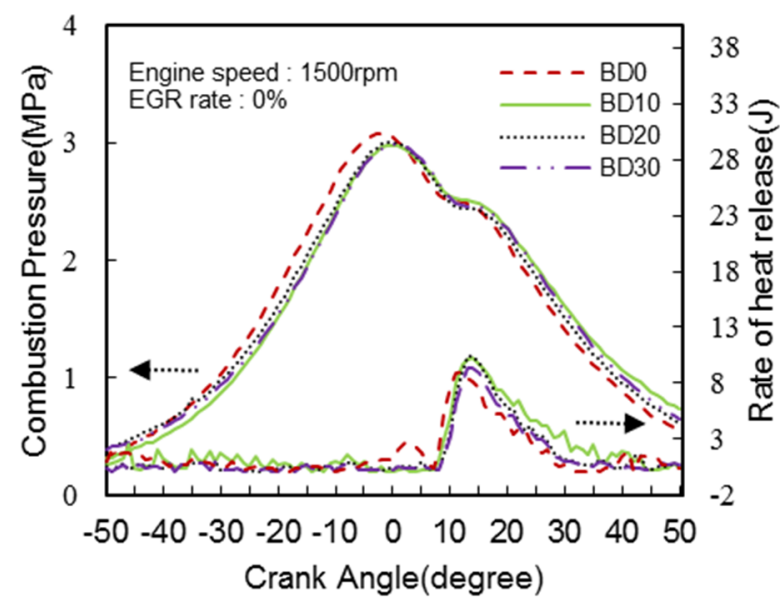

(a)

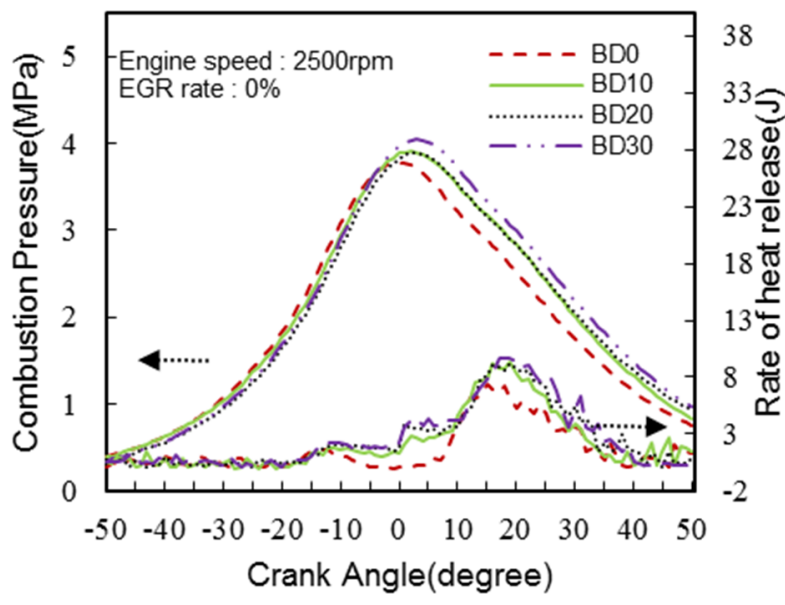

(b)

Figure 3. Effects of the engine speed and biodiesel blend ratio on the (a) peak combustion pressure and (b) indicated mean effective pressure (IMEP).

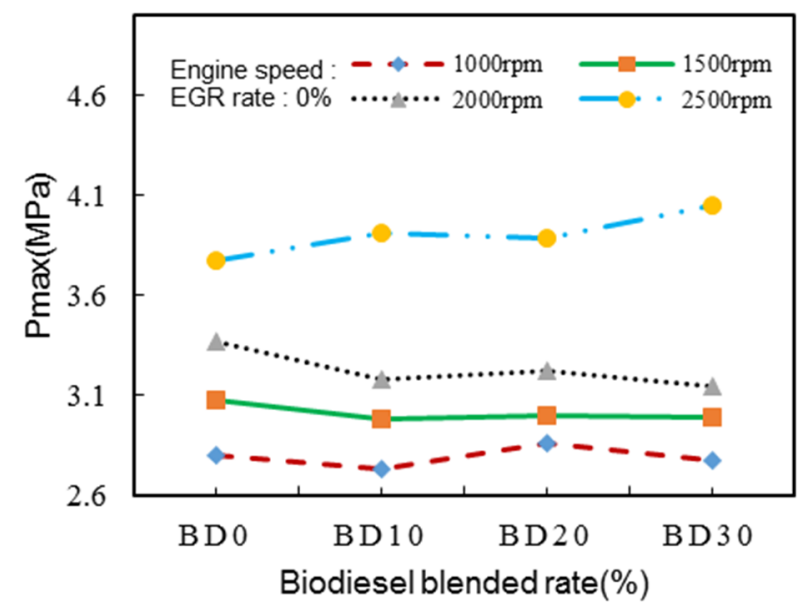

(a)

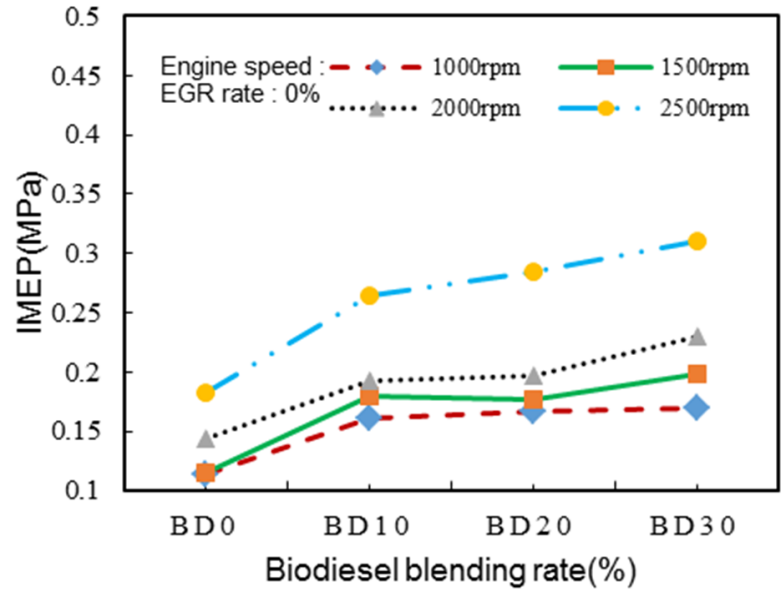

(b)

Figure 4 shows the variation of the BSFC of the engine with ULSD and BD blended fuels at engine speeds of 1000, 1500, 2000, and $2500 \mathrm{rpm}$. With increasing BD blend ratio, the BSFCs of the BD blended fuels compared to ULSD increased at all speeds with the maximum value obtained with BD 30 at $2500 \mathrm{rpm}$. The higher BSFC of BD 30 indicates that more fuel was consumed to produce the same amount of power. This is expected because of the relatively low calorific value of BD 30 compared to ULSD. However, the BD 10 and BD 20 blends showed less of a BSFC increase $(1.9 \%$ and $2.2 \%$ BSFC increases, respectively) at $1000 \mathrm{rpm}$. This indicates that they have higher fuel consumption efficiencies than those of the different BD blended fuels at all speeds. 
Figure 4. Effects of the biodiesel blend ratio and engine speed on the brake specific fuel consumption (BSFC).

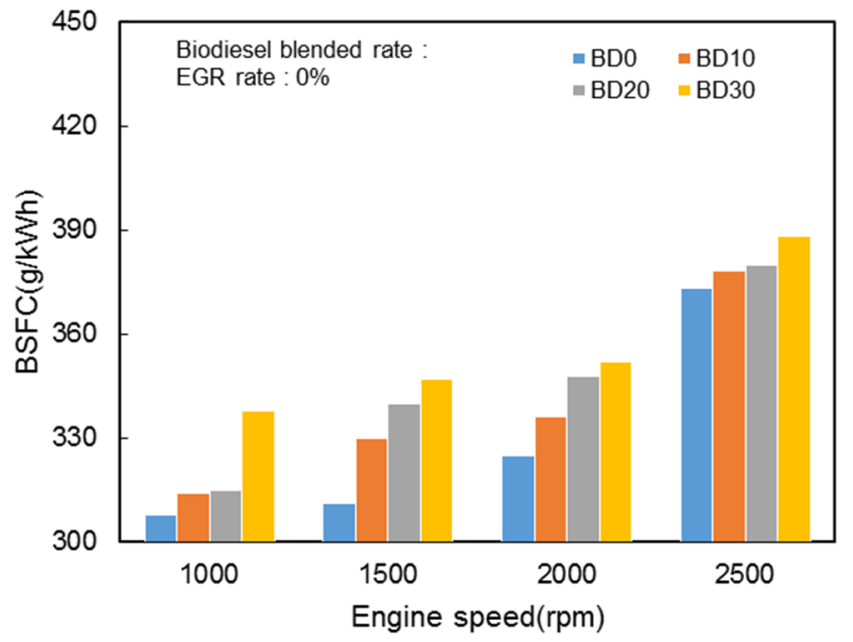

Another important performance parameter is the BSEC. This parameter is often used to compare the performance of fuels with different calorific values. BSEC is defined as the product of the BSFC and heating calorific value of a fuel and corresponds to the amount of energy consumed to develop a unit of output power in one hour. Generally, the value of BSEC decreases with increasing energy consumption. Figure 5 shows the BSEC values of the engine fueled with the various canola oil biodiesel blends compared to BD 0 (pure diesel) at various engine speeds. From the results, it can be seen that engine fueled with BD 0 consistently resulted in the lowest BSEC. The biodiesel fuel blend demonstrates a higher BSEC, which may be related to the lower brake thermal efficiency and some dissimilarities in the combustion processes. However, it did not increase further as the degree of the COME blending increased. This is due to the fact that at a higher degree of COME, the initiation of combustion at an earlier period and efficient combustion due to the increased oxygen content in fuel spray yields a lower BSEC. The highest increase of the BSEC was approximately $6.9 \%$ for BD 30 compared to BD 0 at an engine speed of $1500 \mathrm{rpm}$.

Figure 5. Effects of the biodiesel blend ratio and engine speed on the brake specific energy consumption (BSEC).

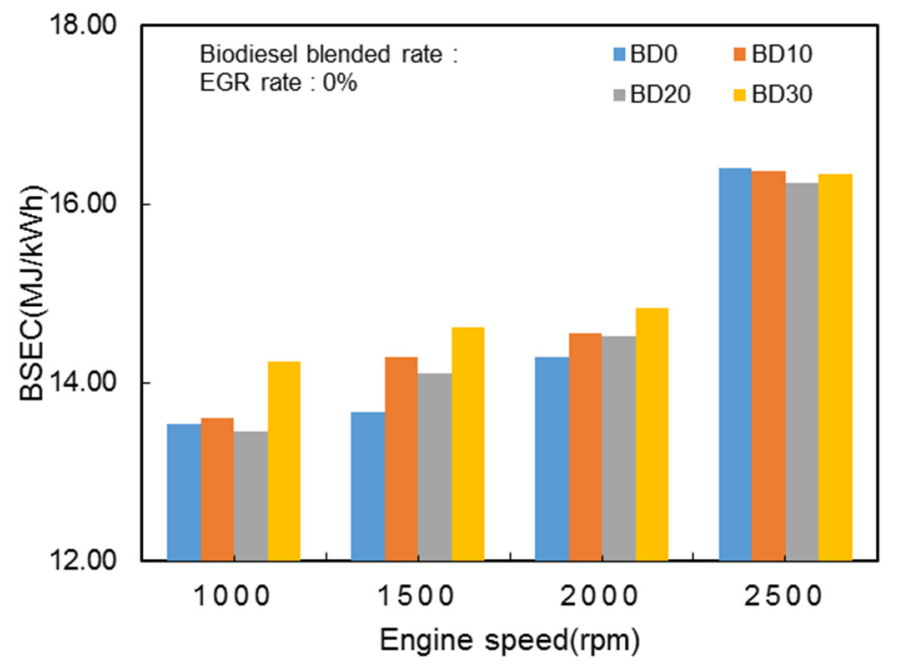




\subsubsection{Exhaust Emissions Characteristics}

Figure 6 shows the $\mathrm{CO}, \mathrm{NO}_{x}$, and $\mathrm{PM}$ emissions depending on the engine speed and the blend ratio of BD without EGR. As shown in Figure 6a, the $\mathrm{CO}$ emissions decreased considerably by $34.8 \%$ with BD 10, 68.5\% with BD 20, and 82.4\% with BD 30 at an engine speed of $1000 \mathrm{rpm}$ compared to the CO emissions obtained for BD 0 . At $1500 \mathrm{rpm}$, the CO emissions were reduced by $26.5 \%$ with BD $10,58.1 \%$ with BD 20, and 66.4\% with BD 30. In the case of an engine speed of $2000 \mathrm{rpm}$, the CO emissions were reduced by $18.5 \%$ with $\mathrm{BD} 10,50 \%$ with $\mathrm{BD} 20$, and $83.2 \%$ with $\mathrm{BD} 30$ compared to the $\mathrm{CO}$ emissions obtained for BD 0 . At an engine speed of $2500 \mathrm{rpm}$, the $\mathrm{CO}$ emissions decreased by $23.4 \%$ with BD 10 , $52.6 \%$ with $\mathrm{BD} 20$, and $83.2 \%$ with $\mathrm{BD} 30$. As the comparative analysis of the experimental results indicates, increases of the BD blend ratio and engine speed resulted in decreased emissions. $\mathrm{CO}$ is a colorless toxic gas that is exhausted when the fuel burns without a sufficient oxygen supply. The increase of the BD blend ratio results in an increase of the oxygen content in the fuel itself and the increasing engine speed induces an increase of the fuel injection pressure.

Figure 6. Effects of the engine speed and biodiesel blend ratio on the (a) brake specific carbon monoxide (BSCO); (b) brake specific nitrogen oxide $\left(\mathrm{BSNO}_{x}\right)$; and (c) brake specific particulate matter (BSPM).

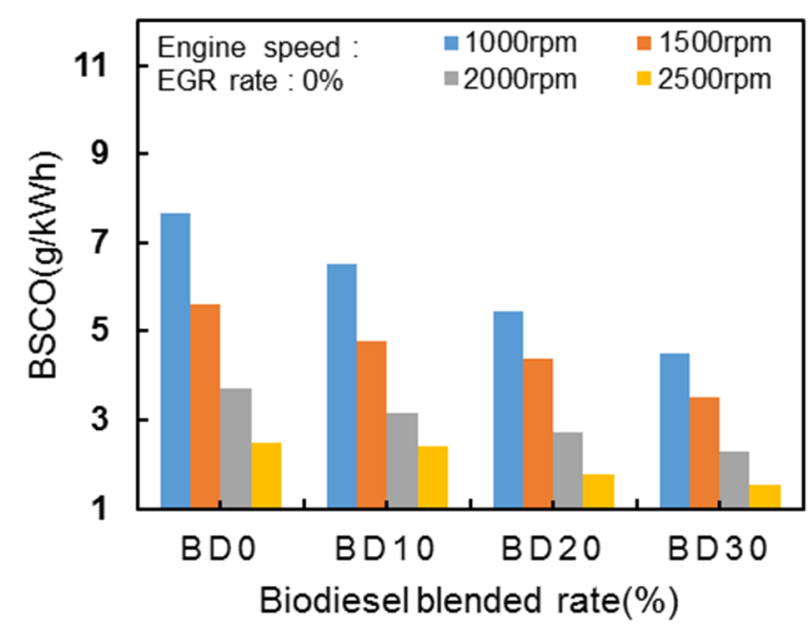

(a)

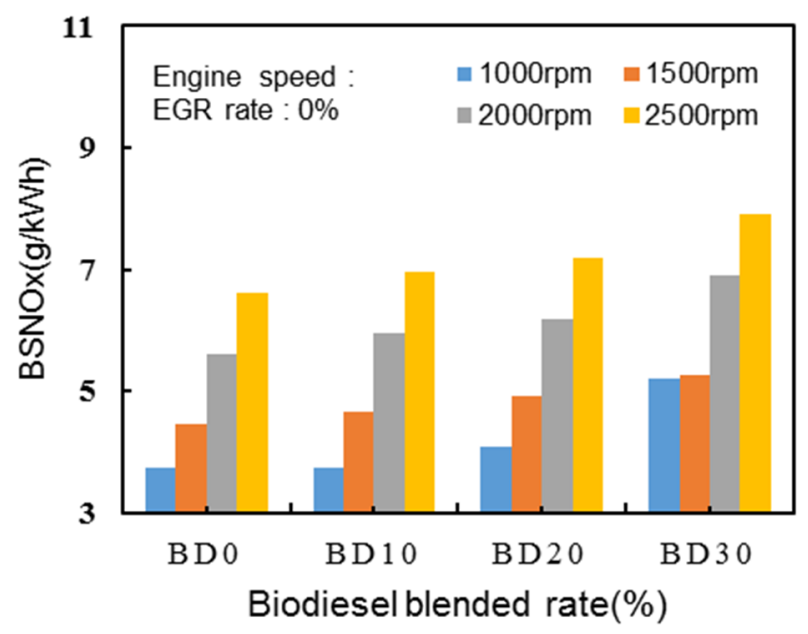

(b)

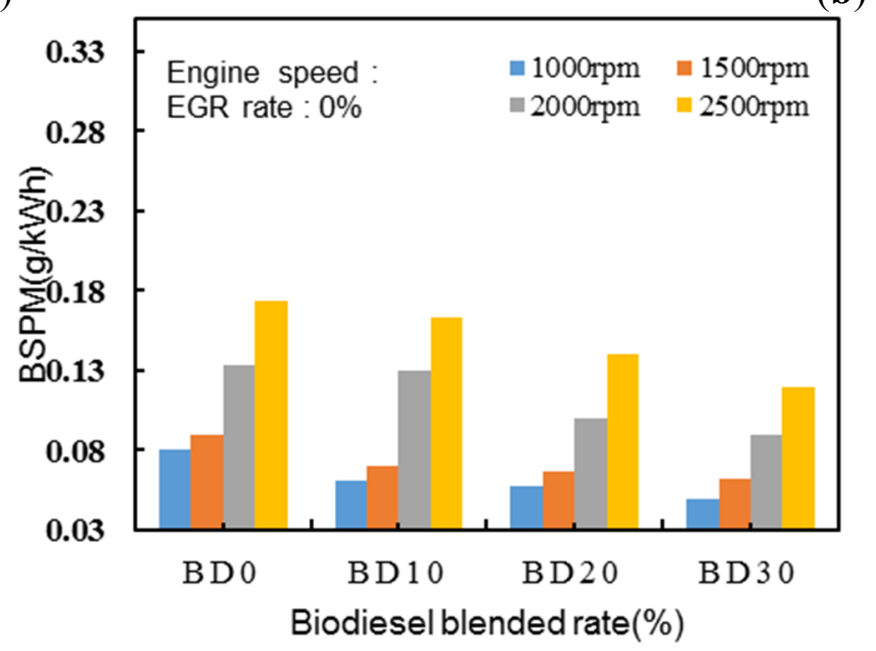

(c) 
For these reasons, fuel is atomized, leading to strong combustion activation. Figure $6 \mathrm{~b}$ shows the $\mathrm{NO}_{x}$ emission results. The $\mathrm{NO}_{x}$ emissions increased under high temperature and high pressure conditions in the combustion chamber. As seen in the Figure 6, the $\mathrm{NO}_{x}$ emissions increased as the BD blend ratio and engine speed increased as described similarly in the article of Ozsezen et al. [15]. The increase of the $\mathrm{NO}_{x}$ emission rate is similar at engine speeds of 1000 and $1500 \mathrm{rpm}$, namely the low speed range, while the $\mathrm{NO}_{x}$ emissions significantly increased up to $14.8 \%$ at $2000 \mathrm{rpm}$ and $22.8 \%$ at $2500 \mathrm{rpm}$ compared to $1000 \mathrm{rpm}$ with $\mathrm{BD} 20$. In addition, as the $\mathrm{BD}$ blend ratio was increased, the $\mathrm{NO}_{x}$ emissions increased more than that of ULSD. It is expected that the high oxygen content in BD results in the increased combustion temperature due to improvement of the burning efficiency. The PM emission results are summarized in Figure 6c.

The PM emissions decreased with increasing BD blend ratio and increased with increasing engine speed. PM is produced by unburned carbon particles when using a densely blended fuel. It is observed that the PM emissions depend on the degree of combustion diffusion related to both the diffusion of fuel vapor separated from fuel drops and the flame diffusion in a dense fuel zone. Accordingly, it can be concluded that exhaust emissions using BD were evaluated to similar results as shown in other experiments $[4,15,34]$.

\subsection{Effect of Biodiesel on the Combustion and Emissions with Exhaust Gas Recirculation}

\subsubsection{Combustion and Engine Performance}

Figure 7 shows the combustion pressure and HRR obtained at an engine speed of $2000 \mathrm{rpm}$ with EGR at the various $\mathrm{BD}$ blend ratios. The combustion pressure decreased as the EGR rate and $\mathrm{BD}$ blend ratio increased at $2000 \mathrm{rpm}$. With BD 0, the combustion pressure decreased by $10.1 \%$ at a $10 \%$ EGR rate, $11.9 \%$ at a $20 \%$ EGR rate, and $12.3 \%$ at a $30 \%$ EGR rate. At BD 30, the combustion pressure increased by $3 \%$ with a $10 \%$ EGR rate, decreased $2.2 \%$ with a $20 \%$ EGR rate, and decreased $4.3 \%$ with a $30 \%$ EGR rate compared to the value obtained with BD 0 . When comparing the HRR at BD 0 with that at $\mathrm{BD}$ 30, as the EGR rate increased, the HRR at BD 0 increased more than that at BD 30. In the case of BD 30, the dissolved oxygen of the BD leads to a small decrease of the ratio. At a $10 \%$ EGR rate with BD 30, the combustion pressure increased 3\% more than that at the $0 \%$ EGR rate because the combustion activation is immediately catalyzed by the dissolved oxygen in the BD itself. As shown in Figure 7, with BD 0 , the HRR decreased by $0.9 \%$ with a $10 \%$ EGR rate, $13.6 \%$ with a $20 \%$ EGR rate, and $18.6 \%$ with a $30 \%$ EGR rate. This behavior appears to be influenced by the poor combustion conditions resulting from the intake of inert gases into the cylinders. With BD 30, even though the EGR rate increases, the HRR increases more than that of ULSD because of the high cetane number and high oxygen content. 
Figure 7. Effects of EGR at biodiesel blend ratios of (a) $0 \%$ and (b) $30 \%$.

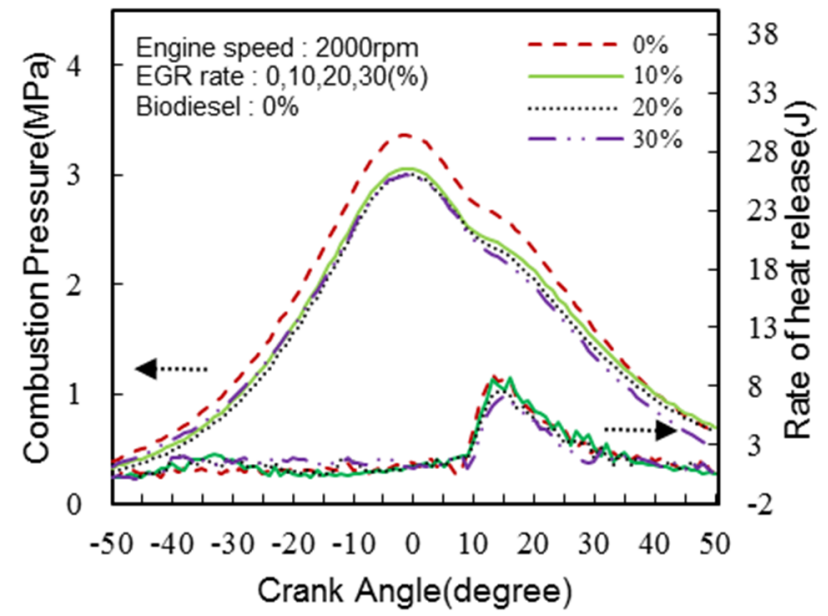

(a)

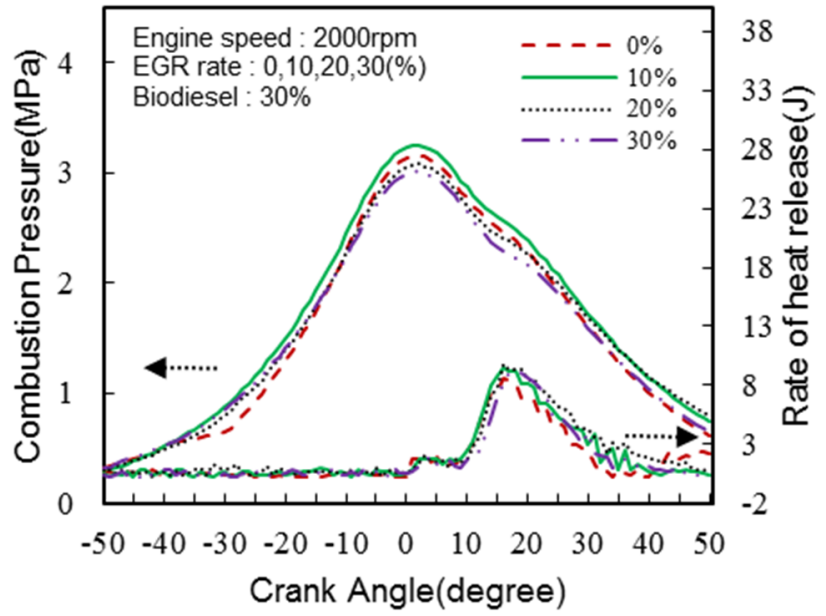

(b)

Figure 8 shows graphs of the peak combustion pressure and IMEP at an engine speed of $2000 \mathrm{rpm}$ with EGR for the various BD blend ratios. Figure 8 a shows that the peak combustion pressure decreases with increasing EGR rate and increases slightly from BD 0 to BD 20 with increasing BD blend ratio. At $\mathrm{BD} 30$, the peak combustion pressure increases $1.6 \%$ with a $0 \%$ EGR rate, $3.9 \%$ with a $10 \%$ EGR rate, $4.5 \%$ with a $20 \%$ EGR rate, and $3.3 \%$ with a $30 \%$ EGR rate compared to the value obtained for BD 0. In Figure 8b, it is seen that the IMEP decreases with increasing EGR rate and increases with increasing BD blend ratio. As shown in Figure 8b, when increasing EGR rate at 2000 rpm, the peak combustion pressure increased slowly with increasing BD blend ratio. At the same time, the IMEP increases remarkably. This occurs because the dissolved oxygen of BD has a strong influence on combustion.

Figure 8. Effects of EGR and the biodiesel blend ratio on the (a) peak combustion pressure and (b) IMEP.

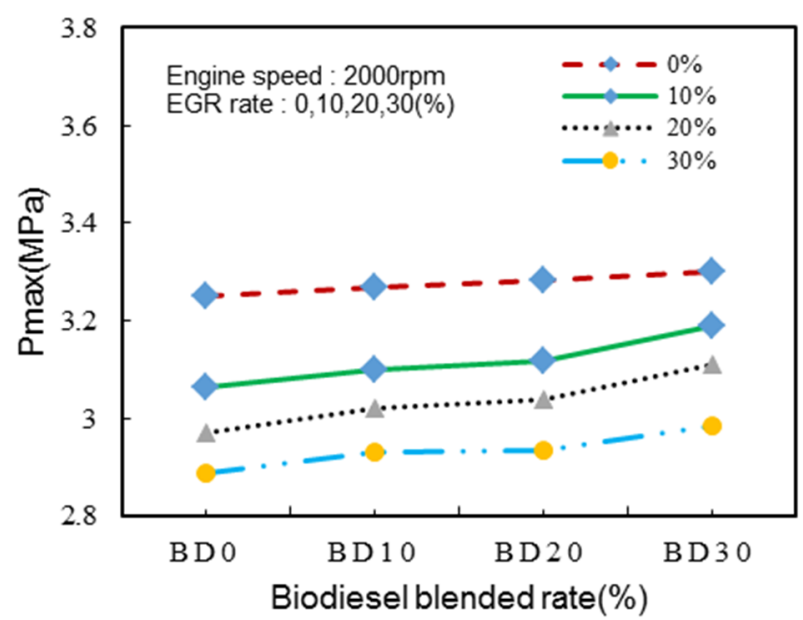

(a)

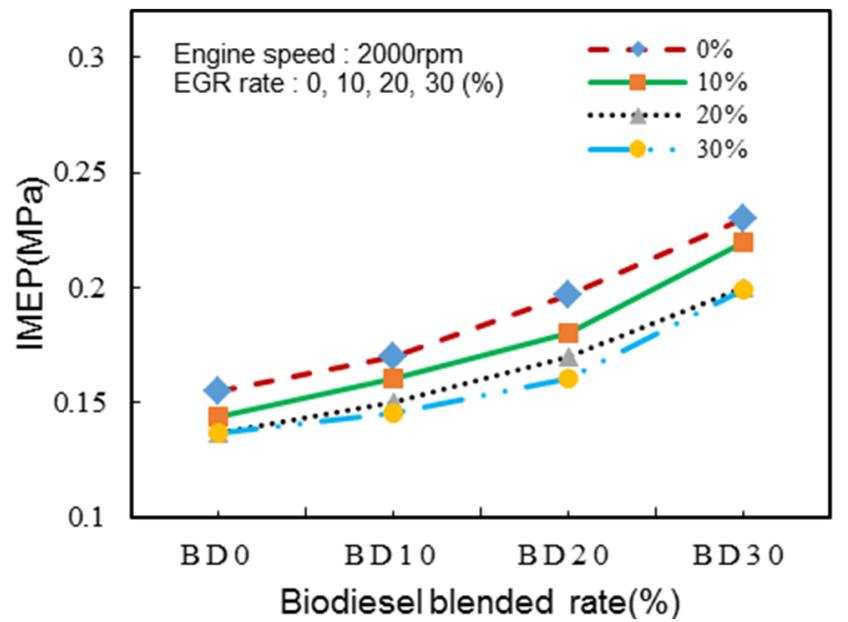

(b)

Figure 9 presents the BSFC of the BD blended fuels obtained at the various EGR rates at $2000 \mathrm{rpm}$. From the results, it is observed that the baseline results without EGR showed the lowest BSFC in the BD blended fuels with EGR. The BSFC increased in proportion to the EGR rate. BD 20 showed the 
lowest BSFCs, which means that BD 20 has the highest fuel conversion efficiency among the different BD blended fuels. These results are in agreement with the results obtained by Cenk et al. [30].

Figure 9. Effects of EGR and the biodiesel blend ratio on the BSFC.

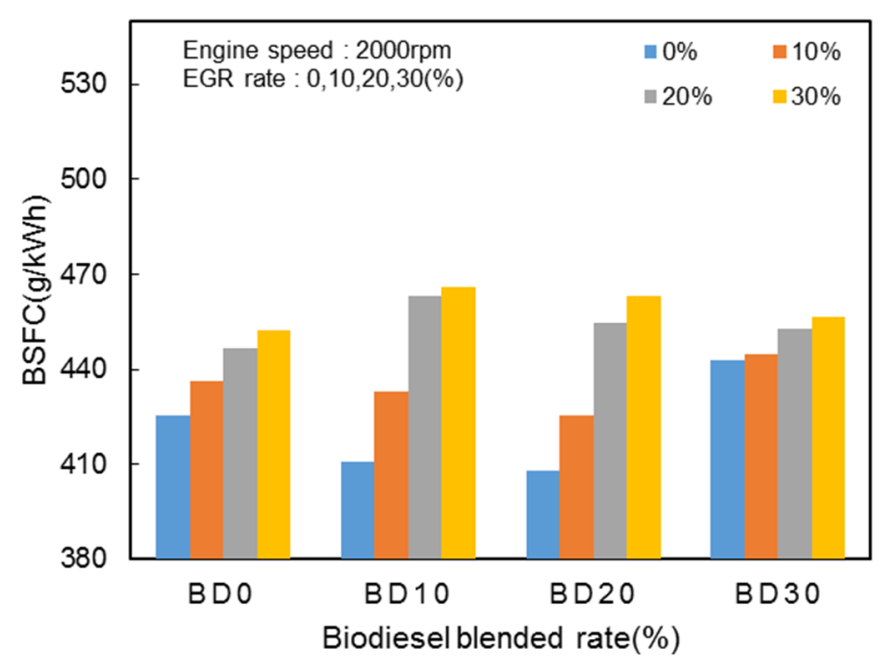

Figure 10 shows the variation of the BSEC of the engine at the different EGR rates and various BD fuel blends at an engine speed of $2000 \mathrm{rpm}$. From the results, it is clear that as the EGR rate increases, the BSEC gradually increases for all fuel blends. In addition, it can be seen that engine fueled without EGR consistently resulted in the lowest BSEC. The biodiesel fuel blend results in a higher BSEC, which is related to the lower brake thermal efficiency and dissimilarities in the combustion processes. The lowest BSEC was approximately $18.15 \mathrm{MJ} / \mathrm{kW} \cdot \mathrm{h}$ for BD 20 at a $10 \%$ EGR rate. However, for BD 30, the BSEC decreased significantly compared to the different blend fuels. This is attributed to the increase of the oxygen content in the BD blended fuels. It is estimated that the combustion of higher BD blend fuels is better than pure diesel fuel combustion.

Figure 10. Effects of EGR and the biodiesel blend ratio on the BSEC.

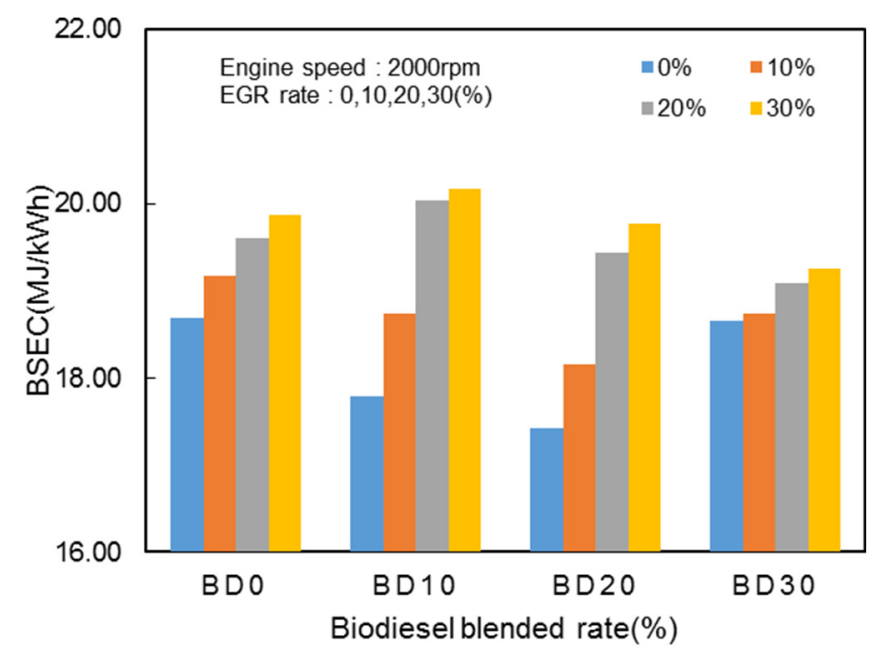




\subsubsection{Exhaust Emissions Characteristics}

The emissions characteristics with EGR at an engine speed of $2000 \mathrm{rpm}$ are shown in Figure 11 as a function of the BD blend ratio. As shown in Figure 11a, the CO emissions increase with increasing EGR rate and decrease with increasing $\mathrm{BD}$ blend ratio. The $\mathrm{CO}$ emissions at an EGR rate of $0 \%$ were reduced by $23.4 \%$ with BD $10,40.3 \%$ with BD 20 , and $64.2 \%$ with BD 30 . At a $10 \%$ EGR rate, the CO emissions decreased by $15.9 \%$ with BD $10,28.4 \%$ with BD 20 , and $34.8 \%$ with BD 30 . At a $20 \%$ EGR rate, the CO emissions were reduced by $11.3 \%$ with BD 10, 25.5\% with BD 20, and $44.8 \%$ with BD 30 compared to the values obtained with $\mathrm{BD} 0$. At an EGR rate of $30 \%$, the $\mathrm{CO}$ emissions decreased by $13.1 \%$ with BD 10, 24.9\% with BD 20, and 45.9\% with BD 30. In these results, it is also obvious that the exhaust gas emissions increase because the exhaust gases recirculated into the cylinders are inert. However, at the same EGR rate, the exhaust gas emissions decreased further with increasing BD blend ratio, which holds sufficient oxygen. Figure $11 \mathrm{~b}$ shows the $\mathrm{NO}_{x}$ emissions depending on the $\mathrm{BD}$ blend ratio at $2000 \mathrm{rpm}$ as a function of the EGR rate. As shown in the figure, the $\mathrm{NO}_{x}$ emissions tended to increase slightly with increasing BD blend ratio and decreased considerably as the EGR rate was increased.

Figure 11. Effects of EGR and the biodiesel blend ratio on the (a) BSCO; (b) $\mathrm{BSNO}_{x}$; and (c) BSPM.

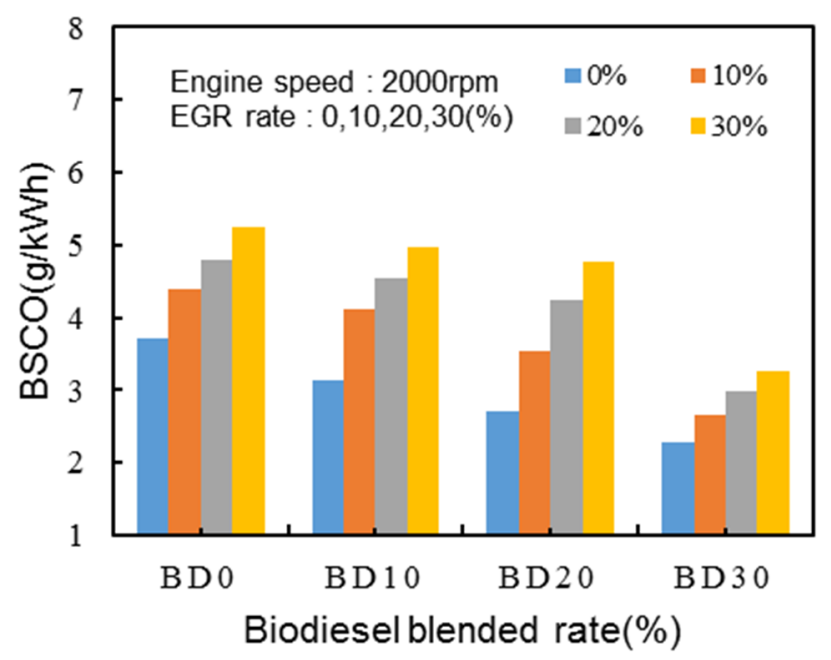

(a)

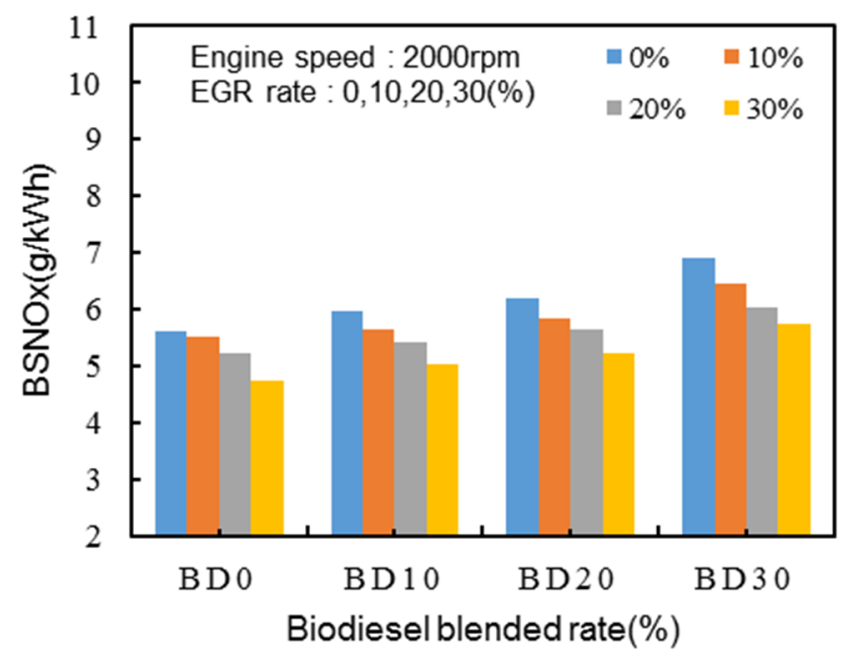

(b)

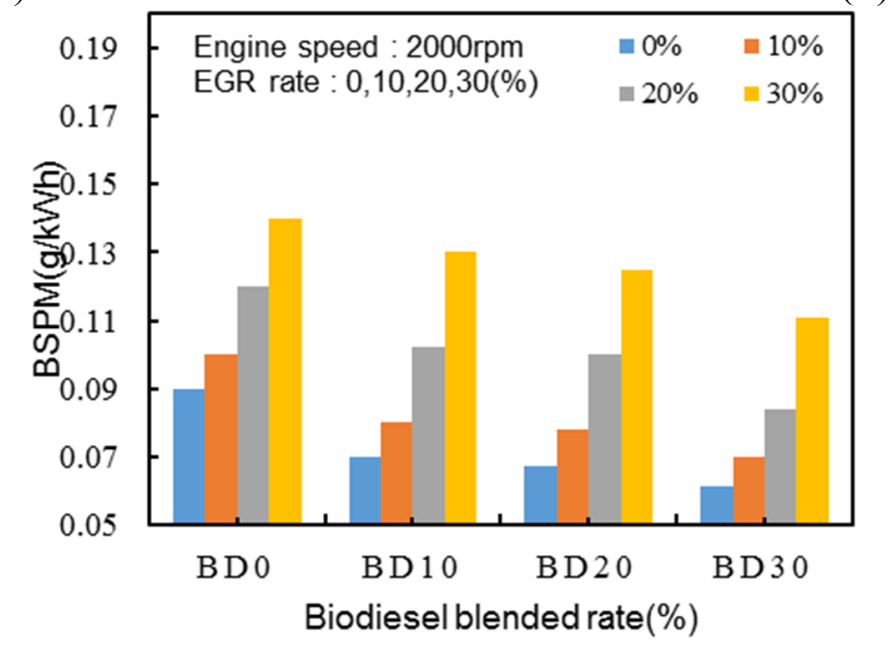

(c) 
Under ideal combustion conditions, namely under a high temperature and high pressure, the $\mathrm{NO}_{x}$ emissions increase. However, recirculated gases, which are burned gases and hold a remarkably low oxygen content in the cylinders, result in poor combustion, which results in reduced $\mathrm{NO}_{x}$ emissions with increasing EGR rate. Figure 11c presents the PM emissions depending on the BD blend ratio obtained at an engine speed of $2000 \mathrm{rpm}$ as the EGR rate was varied. In the graph, the PM emissions decreased with increasing BD blend ratio and increased with increasing EGR rate. As the EGR rate increased, more carbon particles are formed due to incomplete combustion.

\section{Conclusions}

Experiments were conducted to investigate the effects of the BD blend ratio and EGR on the characteristics of combustion and exhaust emissions in a common rail diesel engine. The following conclusions can be drawn from this study:

- When increasing the BD blend ratio at engine speeds of 1000, 1500, 2000, and $2500 \mathrm{rpm}$ without EGR, the combustion pressure and IMEP slightly decreased in the low engine speed range below $2000 \mathrm{rpm}$ while it showed a tendency to increase in the middle engine speed range of $2500 \mathrm{rpm}$.

- As the BD blend ratio increased, compared to ULSD, the BSFC and BSEC increased at all speeds both with and without EGR.

- On the other hand, the CO and PM emissions decreased considerably as the BD blend ratio was increased at every engine speed. In particular, the CO emission decreased by up to $34.8 \%$ with BD 10 at $1000 \mathrm{rpm}$, up to $58.1 \%$ with BD 20 at $2000 \mathrm{rpm}$, up to $83.2 \%$ with BD 30 at $2500 \mathrm{rpm}$, as compared with BD 0 . The PM emissions decreased by about $33 \%$ with BD 30 compared to BD 0 at all engine speeds.

- The PM emissions decreased by about $33 \%$ on average with BD 30 compared to BD 0 at all engine speeds of 1000, 1500, 2000, and $2500 \mathrm{rpm}$ without EGR.

- However, the $\mathrm{NO}_{x}$ emissions increased by up to $14.8 \%$ at $2000 \mathrm{rpm}$ and $22.8 \%$ at $2500 \mathrm{rpm}$ compared to $1000 \mathrm{rpm}$ for BD 20 without EGR.

- While increasing the EGR rate at $10 \%$ intervals from $0 \%$ to $30 \%$ at an engine speed of $2000 \mathrm{rpm}$, it was found that the combustion pressure decreased as the BD blend ratio increased. The $\mathrm{NO}_{x}$ emissions decreased by $4 \%-5 \%$ on average compared to those obtained at a $0 \%$ EGR rate. They also decreased considerably with increasing EGR rate.

- In the case of using the BD 20 blended fuel with EGR in the middle speed range of the engine, the exhaust emissions were considerably reduced without negatively impacting the engine performance.

\section{Acknowledgments}

This work was supported by a grant from the Korean Ministry of Education, Science and Technology (MEST) through the National Research Foundation (NRF) (Project No. 2014-009068) and by Basic Science Research program through the NRF funded by the Ministry of Education (Project No. 2014059723). The authors also thank Zhang Cheng from the Department of Mechanical Design Engineering of Chonbuk National University for his help in performing the engine tests and measurements. 


\section{Author Contributions}

All authors contributed equally to this work. All authors designed the experimental apparatus, discussed the results and implications, and commented on the manuscript at all stages. Sam Ki Yoon performed the engine performance experiments. Han Joo Kim measured the exhaust emissions and Min Soo Kim led the development of the paper. Nag Jung Choi performed the results analysis and discussion.

\section{Conflicts of Interest}

The authors declare no conflict of interest.

\section{References}

1. Agarwal, A.K. Biofuels (alcohols and biodiesels) application as fuels for internal combustion engines. Prog. Energy Combust. Sci. 2007, 33, 233-271.

2. Demirbas, A. Progress and recent trends in biofuels. Prog. Energy Combust. Sci. 2007, 33, 1-18.

3. Graboski, M.S.; McCormick, R.L. Combustion of fat and vegetable oil derived fuels in diesel engines. Prog. Energy Combust. Sci. 1998, 24, 125-164.

4. McCormick, R.L.; Tennant, C.J.; Hayes, R.R.; Black, S. Regulated emissions from biodiesel tested in heavy duty engines meeting 2004 emission standards. In Proceedings of the 2005 SAE Brasil Fuels \& Lubricants Meeting, Rio De Janeiro, Brazil, 11-13 May 2005.

5. Yoon, S.H.; Park, S.H.; Lee, C.S. Experimental investigation on the fuel properties of biodiesel and its blends at various temperatures. Energy Fuels 2008, 22, 652-656.

6. Yoon, S.H.; Lee, C.S. Experimental investigation on the combustion and exhaust emission characteristics of biogas-biodiesel dual-fuel combustion in a CI engine. J. Fuel Process. Technol. 2011, 92, 992-1000.

7. Brian, S.; William, R.M.; Bend, B.; Winfried, D.; Stefan, F. Recent DPF/SCR results targeting US 2007 and EURO 4/5 HD emissions. In Proceedings of the SAE 2003 World Congress \& Exhibition, Detroit, MI, USA, 3-6 March 2003.

8. Yongsheng, H.; David, B.B.; Shuguang, L.; Micheal, J.P.; Jianwen, L. Opportunities and challenges for cleaned 2-way SCR/DPF after treatment technologies. In Proceedings of the SAE World Congress \& Exhibition, Detroit, MI, USA, 20-23 April 2009.

9. Kim, M.Y.; Yoon, S.H.; Lee, C.S. Impact of split injection strategy on the exhaust emissions and PM particulates from a compression ignition engine fueled with neat biodiesel. Energy Fuels 2008, 22, 1260-1265.

10. Kim, M.Y.; Yoon, S.H.; Hwang, J.W.; Lee, C.S. Characteristics of particulate emissions of compression ignition engine fueled with biodiesel derived from soybean. J. Eng. Gas Turbine Power 2008, 130, doi:10.1115/1.2906215.

11. Fathi, M.; Saray, R.K.; Checkel, M.D. The influence of exhaust gas recirculation (EGR) on combustion and emissions of n-heptane/natural gas fueled homogeneous charge compression ignition (HCCI) engine. Appl. Energy 2011, 88, 4719-4724. 
12. Wu, H.W.; Wang, R.H.; Ou, D.J.; Chen, Y.C.; Chen, T.Y. Reduction of smoke and nitrogen oxides of a partial HCCI engine using premixed gasoline and ethanol with air. Appl. Energy 2011, 88, 3882-3890.

13. Oner, C.; Altun, S. Biodiesel production from inedible animal tallow and an experimental investigation of its use as alternative fuel in a direct injection diesel engine. Appl. Energy 2009, 86, 2114-2120.

14. Sahoo, P.K.; Das, L.M.; Babu, M.K.G.; Arora, P.; Singh, V.P.; Kumar, N.R.; Varyani, T.S. Comparative evaluation of performance and emission characteristics of Jatropha, Karanja and Polanga based biodiesel as fuel in a tractor engine. Fuel 2009, 88, 1698-1707.

15. Ozsezen, A.N.; Canakci, M.; Turkcan, A.; Sayin, C. Performance and combustion characteristics of a DI diesel engine fueled with palm oil and canola oil methyl esters. Fuel 2009, 88, 629-636.

16. Choi, C.Y.; Reitz, R.D. An experimental study on the effects of oxygenated fuel blends and multiple injection strategies on DI diesel engine emissions. Fuel 1999, 78, 1303-1317.

17. Cheng, C.H.; Cheung, C.S.; Chan, T.L.; Lee, S.C.; Yao, C.D.; Tsang, K.S. Comparison of emissions of a direct injection diesel engine operating on biodiesel with emulsified and fumigated methanol. Fuel 2008, 87, 1870-1879.

18. Szybist, J.; Simmons, J.; Druckenmiller, M.; Al-Qurashi, K.; Boehaman, A.; Scaroni, A. Potential methods for $\mathrm{NO}_{x}$ reduction from biodiesel. In Proceedings of the SAE Powertrain \& Fluid Systems Conference \& Exhibition, Pittsburgh, PA, USA, 27-30 October 2003.

19. Leung, D.Y.C.; Luo, Y.; Chan, T.L. Optimization of exhaust emissions of a diesel engine fuelled with biodiesel. Energy Fuel 2006, 20, 1015-1023.

20. Ileri, E.; Kocar, G. Effects of antioxidant additives on engine performance and exhaust emissions of a diesel engine fueled with canola oil methyl ester-diesel blend. Energy Convers. Manag. 2013, $76,145-154$.

21. Hass, J.M.; Scott, K.M.; Alleman, T.L.; McCormick, R.L. Engine performance of biodiesel fuel prepared from soybean soap stock: A high quality renewable fuel produced from a waste feedstock. Energy Fuel 2001, 15, 1207-1212.

22. Lapuerta, M.; Armas, O.; Fernandez, J.R. Effect of biodiesel fuels on diesel engine emissions. Prog. Energy Combust. Sci. 2008, 34, 198-223.

23. Lin, B.F.; Huang, J.H.; Huang, D.Y. Experimental study of the effects of vegetable oil methyl ester on DI diesel engine performance characteristics and pollutant emissions. Fuel 2009, 88, 1779-1785.

24. Ferreira, S.L.; Santos, A.M.; Souza, G.R.; Polito, W.L. Analysis of the emissions of volatile organic compounds from the compression ignition engine fueled by diesel-biodiesel blend and diesel oil using gas chromatography. Energy 2008, 33, 1801-1806.

25. He, C.; Ge, Y.S.; Tan, J.W.; You, K.W.; Han, X.K.; Wang, J.F.; You, Q.; Shah, A.N. Comparison of carbonyl compounds emissions from diesel engine fueled with biodiesel and diesel. Atmos. Environ. 2009, 43, 3657-3661.

26. Puhan, S.; Vedaraman, N.; Ram, V.B. Mahua oil (Madhuca indica seed oil) methyl ester as biodiesel preparation and emission characteristics. Biomass Bioenergy 2005, 28, 87-93.

27. Chang, D.Y.Z.; van Gerpen, J.H.; Lee, I.; Johnson, L.A.; Hammond, E.G.; Marley, S.J. Fuel properties and emissions of soybean oil esters as diesel fuel. J. Am. Oil Chem. Soc. 1996, 73, 1549-1555. 
28. Lee, C.S.; Park, S.W.; Kwon, S.I. An experimental study on the atomization and combustion characteristics of biodiesel blended fuels. Energy Fuel 2005, 19, 2201-2208.

29. Jindal, S.; Nandwana, B.P.; Rathore, N.S.; Vashistha, V. Experimental investigation of the effect of compression ratio and injection pressure in a direct injection diesel engine running on Jatropha methyl ester. Appl. Therm. Eng. 2010, 30, 442-448.

30. Cenk, S.; Metin, G.; Mustafa, C. Effect of fuel injection pressure on the injection, combustion and performance characteristics of a DI diesel engine fueled with canola oil methyl esters diesel fuel blends. Biomass Bioenergy 2012, 46, 435-446.

31. Roy, M.M.; Wang, W.; Bujold, J. Biodiesel production and comparison of emissions of a DI diesel engine fueled by biodiesel-diesel and canola oil-diesel blends at high idling operation. Appl. Energy 2013, 106, 198-208.

32. Al-Dawody, M.F.; Bhatti, S.K. Optimization strategies to reduce the biodiesel $\mathrm{NO}_{x}$ effect in diesel engine with experimental verification. Energy Convers. Manag. 2013, 68, 96-104.

33. Heywood, J.B. Internal Combustion Engine Fundamentals; McGraw-Hill Inc.: New York, NY, USA, 1988; pp. 509-510.

34. Ozturk, E. Performance, emissions, combustion and injection characteristics of a diesel engine fuelled with canola oil-hazelnut soapstock biodiesel mixture. Fuel Process. Technol. 2015, 129, 183-191.

(C) 2014 by the authors; licensee MDPI, Basel, Switzerland. This article is an open access article distributed under the terms and conditions of the Creative Commons Attribution license (http://creativecommons.org/licenses/by/4.0/). 